\title{
Mineralocorticoid and glucocorticoid receptors differentially regulate NF-kappaB activity and pro-inflammatory cytokine production in murine BV-2 microglial cells
}

Boonrat Chantong, Denise V Kratschmar, Lyubomir G Nashev, Zoltan Balazs and Alex Odermatt ${ }^{*}$

\begin{abstract}
Background: Microglia, the resident macrophage-like cells in the brain, regulate innate immune responses in the CNS to protect neurons. However, excessive activation of microglia contributes to neurodegenerative diseases. Corticosteroids are potent modulators of inflammation and mediate their effects by binding to mineralocorticoid receptors (MR) and glucocorticoid receptors (GR). Here, the coordinated activities of GR and MR on the modulation of the nuclear factor-KB (NF-KB) pathway in murine BV-2 microglial cells were studied.

Methods: BV-2 cells were treated with different corticosteroids in the presence or absence of MR and GR antagonists. The impact of the glucocorticoid-activating enzyme $11 \beta$-hydroxysteroid dehydrogenase type 1 $(11 \beta-H S D 1)$ was determined by incubating cells with 11-dehydrocorticosterone, with or without selective inhibitors. Expression of interleukin-6 (IL-6), tumor necrosis factor receptor 2 (TNFR2), and 11ß-HSD1 mRNA was analyzed by RT-PCR and IL-6 protein expression by ELISA. NF-KB activation and translocation upon treatment with various corticosteroids were visualized by western blotting, immunofluorescence microscopy, and translocation assays.

Results: GR and MR differentially regulate NF-kB activation and neuroinflammatory parameters in BV-2 cells. By converting inactive 11-dehydrocorticosterone to active corticosterone, 11 $\beta$-HSD1 essentially modulates the coordinated action of GR and MR. Biphasic effects were observed for 11-dehydrocorticosterone and corticosterone, with an MR-dependent potentiation of IL-6 and tumor necrosis factor-a (TNF-a) expression and NF-KB activation at low/moderate concentrations and a GR-dependent suppression at high concentrations. The respective effects were confirmed using the MR ligand aldosterone and the antagonist spironolactone as well as the GR ligand dexamethasone and the antagonist RU-486. NF-KB activation could be blocked by spironolactone and the inhibitor of NF-KB translocation Cay-10512. Moreover, an increased expression of TNFR2 was observed upon treatment with 11-dehydrocorticosterone and aldosterone, which was reversed by $11 \beta$-HSD1 inhibitors and/or spironolactone and Cay-10512.
\end{abstract}

Conclusions: A tightly coordinated GR and MR activity regulates the NF-kB pathway and the control of inflammatory mediators in microglia cells. The balance of GR and MR activity is locally modulated by the action of $11 \beta-H S D 1$, which is upregulated by pro-inflammatory mediators and may represent an important feedback mechanism involved in resolution of inflammation.

Keywords: Mineralocorticoid receptor, Glucocorticoid receptor, 11ß-hydroxysteroid dehydrogenase, Inflammation, Interleukin-6, NF-kB

\footnotetext{
* Correspondence: alex.odermatt@unibas.ch

Division of Molecular and Systems Toxicology, Department of Pharmaceutical

Sciences, University of Basel, Klingelbergstrasse 50, CH-4056, Basel,

Switzerland
} 


\section{Background}

Glucocorticoids are essential for the coordinated regulation of metabolic and immune responses. They are well known due to their potent anti-inflammatory and immune suppressive effects, and therefore widely used in clinics to treat inflammatory and autoimmune diseases. Increasing evidence indicates that endogenously occurring glucocorticoids can, in some situations, stimulate inflammation by enhancing the production of proinflammatory mediators and promoting oxidative stress [1-3]. The underlying mechanisms and the role of corticosteroid receptors are, however, not fully understood.

Glucocorticoids exert their effects mainly by activating glucocorticoid receptors (GR) and mineralocorticoid receptors (MR). A comparison of corticosterone binding to MR and GR in rat hippocampal preparations revealed a 10-fold higher affinity for MR $\left(K_{d}=0.5 \mathrm{nM}\right)$ compared with GR $\left(K_{d}=5.0 \mathrm{nM}\right)[4,5]$. Importantly, hippocampal MR was occupied about $80 \%$ while GR was occupied $10 \%$ only if samples were taken at the nadir of the hypothalamus-pituitary adrenal (HPA) axis diurnal rhythm in the morning. GR binding increased at higher corticosterone levels, suggesting that GR is activated during stress [6,7] and potentially also at diurnal peak levels. Differential binding by MR and GR in various brain cells needs to be considered in order to understand effects of glucocorticoids in the CNS [8-10].

In classical mineralocorticoid target tissues involved in electrolyte and volume regulation, such as renal cortical collecting ducts, distal colon, and salivary and sweat glands, MR is co-expressed with $11 \beta$-hydroxysteroid dehydrogenase 2 (11 $\beta$-HSD2), which converts active (corticosterone, cortisol) into inactive glucocorticoids (11-dehydrocorticosterone, cortisone) [11-13]. The close proximity of $11 \beta-H S D 2$ and MR has been proposed to prevent MR activation by glucocorticoids, thereby rendering specificity of the receptor to aldosterone [14]. Deficient $11 \beta$-HSD2 activity has been shown to result in sodium and water retention, causing edema formation and hypertension [15-17]. To avoid these adverse effects caused by excessive activation of renal and intestinal MR, synthetic glucocorticoids selectively activating GR have been designed and are widely used in therapy of inflammatory and autoimmune diseases $[18,19]$.

Besides, MR has important functions in vascular cells, adipocytes, osteocytes, neutrophils, dendritic cells, and macrophage [11]. In the brain, MR plays an important role in hippocampal neurons and in immune cells [2022]. Glucocorticoids are essentially involved in the modulation of the coordinated action of monocytes, macrophages, astrocytes, and microglia cells during inflammation in the brain [23]. Interestingly, in macrophage and microglia cells, MR and GR are co-expressed in the presence of $11 \beta$-HSD1, which converts inactive 11-dehydrocorticosterone and cortisone into active corticosterone and cortisol [11]. Since circulating glucocorticoid concentrations are 100 to 1,000 times higher than those of aldosterone, MR activity is most likely controlled by glucocorticoids but not aldosterone in these cells under physiological conditions [24].

So far, only few cell lines have been reported that express MR, GR, and 11 $\beta$-HSD1 at sufficient levels, allowing to investigate the functional interactions between the two corticosteroid receptors and to assess the role of $11 \beta-H S D 1$ in regulating their activities. In the present study, we show that the murine microglial cell line BV-2, which is considered to be a suitable model of microglia to study inflammatory parameters [25], expresses MR, GR, and $11 \beta-H S D 1$. We compared the effects of the endogenous glucocorticoids 11-dehydrocorticosterone (which requires activation by $11 \beta-H S D 1)$ and corticosterone, the mineralocorticoid aldosterone and the synthetic glucocorticoid dexamethasone on NF- $\mathrm{KB}$ activation and IL-6 expression in the presence or absence of MR and GR antagonists. Moreover, the impact of pro-inflammatory cytokines and corticosteroids on the expression of TNFR2 and $11 \beta-H S D 1$ was investigated.

\section{Methods}

\section{Materials}

Fetal bovine serum (FBS) was purchased from Atlanta Biologicals (Lawenceville, GA, USA) and other cell culture media and supplements from Invitrogen (Carlsbad, CA, USA). Escherichia coli 0111:B4 lipopolysaccharide (LPS), TNF $\alpha$, and IL-6 were purchased from SigmaAldrich (St. Louis, MO, USA), Cay-10512 was from Cayman Chemicals (Hamburg, Germany), $\left[1,2-{ }^{3} \mathrm{H}\right]$-cortisone from American Radiolabeled Chemicals (St. Louis, MO, USA), IL-6 ELISA kit from BD Biosciences (Allschwil, Switzerland), and the HCS kit for evaluation of NF-kB activation (K010011) was obtained from Cellomics ThermoScientific (Pittsburgh, PA, USA). Antibodies against HDAC-1, TNFR2, NF- $\mathrm{kB}$ subunit p65, and phosphorylated p65 were obtained from Cell Signaling Technology (Danvers, MA, USA). Antibody against $\beta$-actin and goat anti-rabbit IgG-HRP were obtained from Santa Cruz Biotechnology (Santa Cruz, CA, USA).

\section{Cell culture}

The immortalized mouse microglial cell line BV-2, developed by Blasi et al. [26,27], was kindly provided by Professor Wolfgang Sattler, University of Graz, Graz, Austria. Cells were cultivated in RPMI-1640 medium supplemented with $10 \%$ FBS, $2 \mathrm{mM}$ glutamine, $100 \mu \mathrm{g} / \mathrm{mL}$ streptomycin, $100 \mathrm{U} / \mathrm{mL}$ penicillin, $0.1 \mathrm{mM}$ non-essential amino acids, and $10 \mathrm{mM}$ HEPES, $\mathrm{pH}$ 7.4. Prior to treatment, cells were seeded in 96-well $\left(1 \times 10^{3}\right.$ cells $)$, 24-well 
$\left(2 \times 10^{4}\right.$ cells $)$, 12 -well $\left(5 \times 10^{5}\right.$ cells $)$, or 6 -well $\left(1 \times 10^{6}\right.$ cells) plates in Dulbecco's modified Eagle's medium (DMEM) supplemented as indicated above and incubated for $24 \mathrm{~h}$ at $37^{\circ} \mathrm{C}$. All experiments were performed under the permission A070126 by the Swiss Federal Department of Environment BAFU.

\section{Quantification of mRNA expression}

Total RNA from treated cells was isolated using Trizol reagent according to the protocol from the manufacturer (Invitrogen). The concentration and purity of the total RNA was assessed by a NanoDrop ${ }^{\circledR}$ spectrophotometer. A $260 / 280 \mathrm{~nm}$ absorbance ratio of 1.8 or higher was accepted for purity of total RNA. Total RNA was used for cDNA synthesis with oligo-dT primers and the Superscript-III first-strand synthesis system (Invitrogen). Total RNA $(0.5 \mu \mathrm{g})$ and oligo-dT primers $(0.5 \mu \mathrm{g})$ were incubated for $5 \mathrm{~min}$ at $56^{\circ} \mathrm{C}$, followed by addition of $4.90 \mu \mathrm{L}$ of $5 \times$ first strand buffer, $1.5 \mu \mathrm{L}$ of $0.1 \mathrm{M}$ dithiothreitol (DTT), $0.5 \mu \mathrm{L}$ of RNAse $\mathrm{H}$ inhibitor (50 U), $1 \mu \mathrm{L}$ of $10 \mathrm{mM}$ dNTPs, and $0.1 \mu \mathrm{L}$ of Supersript ${ }^{\circledR}$ Reverse Transcriptase III (total reaction volume $24.5 \mu \mathrm{L}$ ). The reaction was performed for $1 \mathrm{~h}$ at $42^{\circ} \mathrm{C}$, followed by adding $80 \mu \mathrm{L}$ of DEPC-treated water and storage at $-20^{\circ} \mathrm{C}$ until further use. Relative quantification of mRNA expression levels was performed by real-time RT-PCR using the KAPA SYBR ${ }^{\circledR}$ FAST qPCR Kit (Kapa Biosystems, Boston, MA, USA) and gene-specific oligonucleotide primers. Quantitative real-time RT-PCR was performed in a final volume of $20 \mu \mathrm{L}$ and using a RotorGene 6000 thermal cycler (Corbett Research, Sydney, Australia). The following amplification procedure was applied: initial denaturation for $15 \mathrm{~min}$ at $95^{\circ} \mathrm{C}$, followed by 40 cycles of denaturation for $15 \mathrm{~s}$ at $94^{\circ} \mathrm{C}$, annealing for $30 \mathrm{~s}$ at $56^{\circ} \mathrm{C}$, and extension for $30 \mathrm{~s}$ at $72^{\circ} \mathrm{C}$. Three replicates were analyzed per sample. Relative gene expression compared with the internal control GAPDH was determined using the $2^{-\Delta \Delta C T}$ method [28]. The oligonucleotide primers for real-time RT-PCR are listed in Additional file 1: Table S1.

\section{Determination of IL- 6 protein expression}

Cells grown in 96-well plates were treated for $24 \mathrm{~h}$ with the compounds indicated, and cell-free supernatants were collected. IL-6 protein was measured using an ELISA kit from BD Biosciences. Briefly, a 96-well plate was coated with capture antibody overnight at $4{ }^{\circ} \mathrm{C}$, followed by washing five times with PBS-T (PBS containing $0.05 \%$ Tween-20). The wells were blocked with assay diluents for $1 \mathrm{~h}$ and washed five times. Standards and collected culture supernatants were added to the appropriate wells and samples were incubated for $2 \mathrm{~h}$. After rinsing five times with PBS-T, each well was incubated with detection antibody for $1 \mathrm{~h}$. After washing, avidin-
HRP was added for 30 min. After rinsing seven times, each well was incubated with substrate solution for $30 \mathrm{~min}$ in the dark. Reaction was stopped by adding $1 \mathrm{M}$ $\mathrm{H}_{3} \mathrm{PO}_{4}$, and the plate was analyzed by measuring absorbance at $450 \mathrm{~nm}$ and subtracting the values at $570 \mathrm{~nm}$ using a UV-max kinetic microplate reader (Molecular Device, Devon, UK). IL-6 protein concentrations were calculated according to the standard curve of purified mouse IL-6.

\section{Determination of NF-KB localization by fluorescence microscopy}

BV-2 cells were grown on poly-L-lysine coated glass slides in 6-well plates. Following treatment, the medium was removed and cells were fixed and stained using Cellomics ${ }^{\circledR}$ NF- $\mathrm{kB}$ p65 activation HCS kit (Cellomics ThermoScientific, Pittsburgh, PA, USA) according to the manufacturer's instructions. Briefly, cells were fixed with $4 \%$ paraformaldehyde in PBS for $15 \mathrm{~min}$ at $25^{\circ} \mathrm{C}$, washed three times with PBS, and permeabilized with PBS containing $0.5 \%$ Triton $\mathrm{X}-100$ for $10 \mathrm{~min}$. After three washes with PBS and blocking with $1 \%$ fatty acid-free bovine serum albumin for $1 \mathrm{~h}$ the samples were incubated with rabbit polyclonal antibody against the p65 subunit of NF- $\mathrm{kB}(1: 500)$ for $2 \mathrm{~h}$ at $37^{\circ} \mathrm{C}$. After washing, slides were incubated in the dark with blocking buffer containing goat anti-rabbit IgG conjugated to Alexa Fluor 488 and Hoechst 33342 dye for $1 \mathrm{~h}$. Slides were washed with PBS and mounted with Mowiol $^{\circledR}$ 4-88 antifade reagent (Hoechst, Frankfurt, Germany) on glass slides. Cells were analyzed using a confocal laser scanning microscope Olympus Fluoview FV1000. Images were captured using a magnification of $400 \times$. The excitation and emission wavelengths were $488 \mathrm{~nm}$ and $510 \mathrm{~nm}$, respectively.

Alternatively, cells were grown in 96-well plates, fixed and stained using Cellomics NF-kB p65 activation HCS reagent kit. The cells were soaked in PBS at $4^{\circ} \mathrm{C}$ until imaging procedure. The assay plate was analyzed on a Cellomics ArrayScan HCS reader. The Cytoplasm to Nucleus Translocation BioApplication software was used to calculate the ratio of cytoplasmic and nuclear NF- $\mathrm{kB}$ intensity [29]. The average intensity of 500 objects (cells) per well was quantified (magnification 200×). Nuclear stain (Hoechst 33342) was in channel 1 and NF- $\kappa B$ was visualized in channel 2 . In channel 2 an algorithm was utilized to identify the nucleus and surrounding cytoplasm in each cell; this analysis method reports the average intensity within each nuclear mask as well as the total of the nuclear and cytoplasmic intensity. The results were reported as percentage of nuclear intensity from total intensity. All treatments were performed in triplicate. 


\section{Preparation of whole cell lysates and cytoplasmic and nuclear fractions}

For preparation of whole cell lysates, cells grown in 6-well plates were washed twice with ice-cold PBS and lysed in cold RIPA buffer (Sigma-Aldrich) supplemented with protease inhibitor cocktail (Roche Diagnostics, Rotkreuz, Switzerland). The extract was centrifuged at $10,000 \times \mathrm{g}$ for $15 \mathrm{~min}$ at $4^{\circ} \mathrm{C}$ to remove cell debris.

For preparation of cytoplasmic and nuclear fractions cells were washed twice with PBS, harvested in $500 \mu \mathrm{L}$ PBS, followed by centrifugation at $450 \times \mathrm{g}$ for $5 \mathrm{~min}$. Cell pellets were washed once with PBS, transferred to 1.5$\mathrm{mL}$ tubes and pelleted again at $1,000 \times \mathrm{g}$ for $5 \mathrm{~min}$. The cells were lysed by gentle resuspension in $200 \mu \mathrm{L}$ lysis buffer containing $0.01 \mathrm{M}$ DTT and protease inhibitors, followed by incubation on ice for $15 \mathrm{~min}$. IGEPAL CA630 solution (Sigma-Aldrich) was added at $0.6 \% \mathrm{v} / \mathrm{v}$ final concentration and samples were vigorously mixed for $10 \mathrm{~s}$, followed by centrifuging at $10,000 \times \mathrm{g}$ for $30 \mathrm{~s}$. Supernatants (cytoplasmic fractions) were transferred to new tubes. The nuclear pellets were washed once with $100 \mu \mathrm{L}$ PBS, pelleted at $450 \times \mathrm{g}$ for $5 \mathrm{~min}$, and resuspended in $100 \mu \mathrm{L}$ of extraction buffer containing $0.01 \mathrm{M}$ DTT and protease inhibitors. Nuclear suspension was agitated for $30 \mathrm{~min}$ and centrifuged at $12,000 \times \mathrm{g}$ for $5 \mathrm{~min}$. Nuclear fractions were frozen at $-80^{\circ} \mathrm{C}$ and thawed on ice to increase extraction of nuclear proteins from the insoluble material. Nuclear samples were then sonicated on ice three times for $5 \mathrm{~s}$ each to obtain the final nuclear fractions.

\section{Detection of protein expression}

Protein concentrations were determined using the Pierce $^{\circledR}$ BCA protein assay kit (Thermo Scientific) according to the manufacturer's instructions and bovine serum albumin as standard. Cytoplasmic, nuclear, or whole cell extracts (30 $\mu$ g per sample) were resolved on $8 \%$ sodium dodecyl sulfate-polyacrylamide gel electrophoresis (SDS-PAGE). Proteins were then transferred to $0.2 \mu \mathrm{m}$ polyvinylidene difluoride (PVDF) membranes (Bio-Rad Laboratories, Hercules, CA, USA). Membranes were incubated in Tris-buffered saline, $\mathrm{pH}$ 7.4, containing $0.1 \%$ Tween-20 (TBS-T), and supplemented with 5\% non-fat milk overnight at $4^{\circ} \mathrm{C}$ for blocking. The blots were then incubated with primary antibodies against the p65 subunit of NF- $\kappa B$ (1:500), the phosphorylated form of p65 (1:500), TNFR2 (1:1,000), HDAC1 $(1: 1,000)$ or $\beta$-actin $(1: 1,000)$ for $2 \mathrm{~h}$ at room temperature. After washing with TBS-T, blots were incubated with goat anti-rabbit IgG-horseradish peroxidase or anti-mouse IgG-horseradish peroxidase $(1: 5,000)$ for $1 \mathrm{~h}$ at room temperature. Blots were washed with TBS-T and immunolabeling was visualized using enhanced chemiluminescence HRP substrate (Millipore, Billerica, MA, USA) according to the manufacturer's instructions using a Fujifilm LAS-4000 detection system (Bucher Biotec, Basel, Switzerland). $\beta$-actin was used as loading control for cytoplasmic and whole cell protein extracts. HDAC1 was used as loading control for nuclear fractions.

\section{$11 \beta-H S D 1$ activity measurements in intact BV-2 cells}

BV-2 cells were grown in 24-well plates and treated with $20 \mathrm{ng} / \mathrm{mL}$ LPS in the presence or absence of $200 \mathrm{nM}$ cortisone for $24 \mathrm{~h}$. Medium was removed and replaced by assay medium containing $50 \mathrm{nM}$ cortisone with 10 nCi $\left[{ }^{3} \mathrm{H}\right]$ cortisone as tracer. Following incubation for $12 \mathrm{~h}$ at $37^{\circ} \mathrm{C}$, medium was collected and steroids were extracted with ethyl acetate. The extracts were dried under vacuum, reconstituted with methanol containing a mixture of $2 \mathrm{mM}$ unlabeled cortisone and cortisol, and steroids were separated in a chloroform/ methanol solvent system $(9: 1, \mathrm{v} / \mathrm{v})$. The conversion of cortisone to cortisol was determined by scintillation counting.

\section{Statistical analysis}

The data were analyzed using one-way ANOVA (V5.00; GraphPad Prism Software Inc., San Diego, CA, USA). When ANOVA showed significant differences between groups, Tukey's post hoc test was used to determine whether specific pairs of groups showed statistically significant differences. $P<0.05$ was considered statistically significant.

\section{Results}

Potentiation of LPS-induced pro-inflammatory cytokine expression by low concentrations of endogenous glucocorticoids

To test whether the murine microglia cell line BV-2 might represent a suitable cell system to study the role of corticosteroid receptors and local glucocorticoid activation on pro-inflammatory cytokine production, we first determined the mRNA expression of GR, MR, and 11ß-HSD1 using real-time RT-PCR. Substantial levels of mRNA expression for all three genes were detected. Approximately 10-fold higher GR mRNA than MR mRNA expression was obtained, in line with evidence for an order of magnitude higher expression of GR compared with MR in the kidney [30]. Thus, the expression pattern suggests that BV-2 cells can be used to investigate mechanisms of corticosteroid-mediated modulation of NF-kB activation and pro-inflammatory cytokine expression.

BV-2 cells are sensitive to LPS, and incubation with LPS resulted in a concentration-dependent increase in the expression of TNF- $\alpha$ mRNA (Figure 1A). It is important to note that the absolute response depends on the batch of LPS and on batch and state of BV-2 cells. 


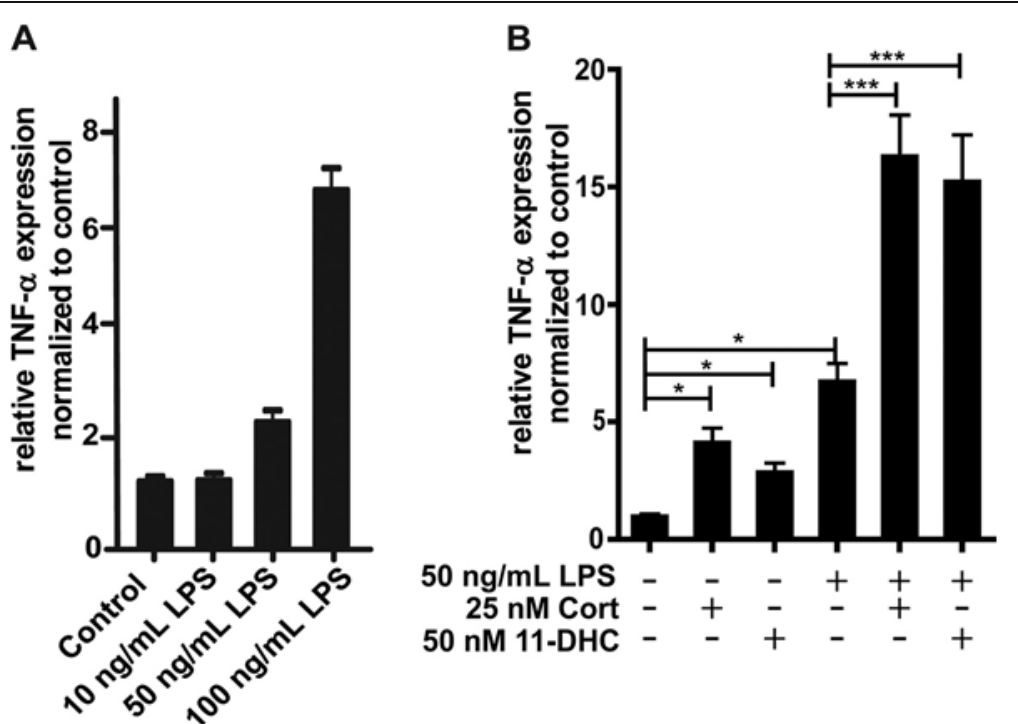

Figure 1 Potentiation of LPS-induced TNF-a mRNA expression by low concentrations of corticosterone. (A) BV-2 cells were incubated with 10, 50, and $100 \mathrm{ng} / \mathrm{mL}$ LPS for $24 \mathrm{~h}$. (B) Cells were exposed to $50 \mathrm{nM}$ 11-dehydrocorticosterone, which requires conversion to corticosterone by $11 \beta-H S D 1$, or $25 \mathrm{nM}$ corticosterone for $24 \mathrm{~h}$ prior to incubation with $50 \mathrm{ng} / \mathrm{mL}$ LPS for another $24 \mathrm{~h}$. TNF-a mRNA expression was measured by real-time RT-PCR. Data (mean \pm SD of three independent experiments) represent ratios of TNF-a mRNA to GAPDH control mRNA from treated cells normalized to the values obtained from cells incubated with vehicle (DMSO). ${ }^{*} P<0.05$, ${ }^{* *} P<0.005$.

The three independent experiments shown in Figure 1A were performed with different batches of LPS and BV-2 cells than the three independent experiments shown in Figure 1B. Another factor influencing the absolute response values is the composition of the culture medium. Performing the experiments shown in Figure 1B in medium with charcoal-treated FBS resulted in almost two-fold higher TNF- $\alpha$ mRNA expression levels, whereby the relative expression changes were comparable (data not shown). As shown in Figure 1B preincubation of cells for $24 \mathrm{~h}$ with $25 \mathrm{nM}$ corticosterone, corresponding to low physiological glucocorticoid concentrations, resulted in a pronounced stimulation of TNF- $\alpha$ expression upon treatment with LPS. Comparable effects, although somewhat less efficient, were observed when using 11-dehydrocorticosterone as substrate. This suggests a pro-inflammatory effect of low endogenous glucocorticoid concentrations and a role of the
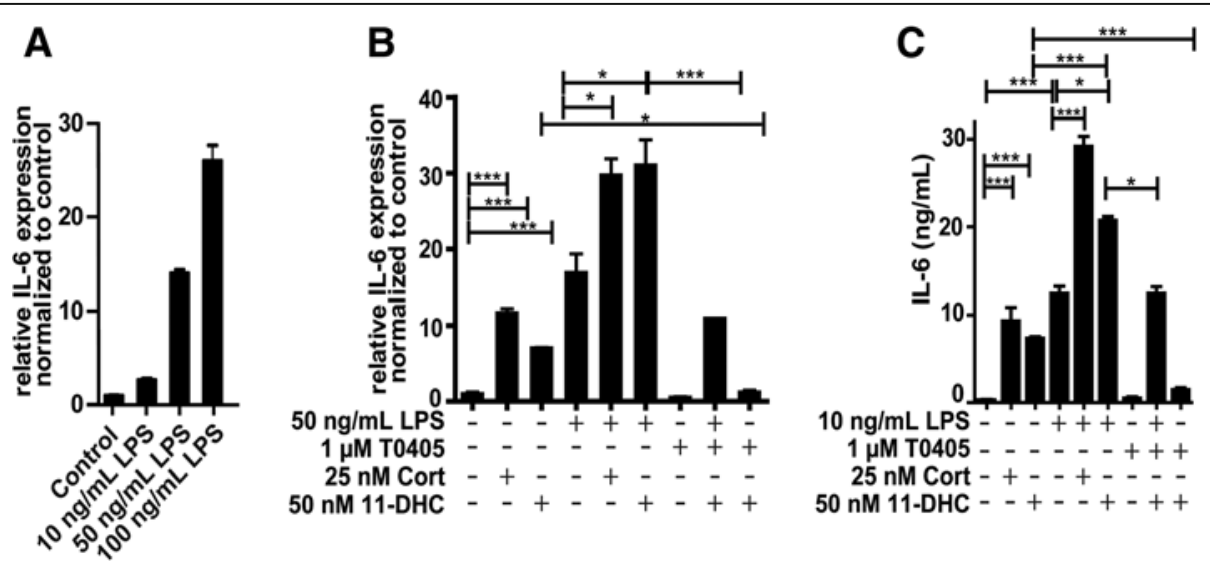

Figure 2 Inhibition of 11ß-HSD1 reversed the 11-dehydrocorticosterone-dependent stimulation of LPS induced IL-6 expression.

(A, B) IL-6 mRNA expression was measured by real-time RT-PCR. Ratios of IL-6 mRNA to GAPDH control mRNA of treated cells were normalized to values obtained from cells incubated with vehicle (DMSO). (A) BV-2 cells were treated for $24 \mathrm{~h}$ with LPS. (B) Cells were pretreated for $24 \mathrm{~h}$ with $25 \mathrm{nM}$ corticosterone or with $50 \mathrm{nM}$ 11-dehydrocorticosterone in the presence or absence of $1 \mu \mathrm{M}$ of the 11ß-HSD1 inhibitor T0504, followed by incubation with $50 \mathrm{ng} / \mathrm{mL}$ LPS for an additional $24 \mathrm{~h}$. (C) IL-6 protein levels were quantified by ELISA. Cells were treated for $24 \mathrm{~h}$ with $25 \mathrm{nM}$ corticosterone or with $50 \mathrm{nM}$ 11-dehydrocorticosterone in the presence or absence of $1 \mu \mathrm{M}$ T0504, followed by $10 \mathrm{ng} / \mathrm{mL}$ LPS for an additional $24 \mathrm{~h}$. Data normalized to control represent mean \pm SD from three independent experiments. ${ }^{*} P<0.05,{ }^{* * *} P<0.005$. 
glucocorticoid-activating enzyme $11 \beta-H S D 1$ in stimulating inflammation.

We measured IL-6 expression as an accepted read-out to assess the sensitivity of exposure to LPS and subsequent activation of NF- $\mathrm{BB}$ [31]. LPS induced IL-6 expression in a concentration-dependent manner (Figure 2A).
Preincubation with $25 \mathrm{nM}$ corticosterone potentiated IL-6 expression (Figure 2B). A similar stimulation of IL-6 expression was observed upon preincubation with $50 \mathrm{nM}$ 11-dehydrocorticosterone, an effect which was reversed by the two structurally distinct selective 11ß-HSD1 inhibitors BNW-16 [32] (data not shown) and T0504

\section{A}

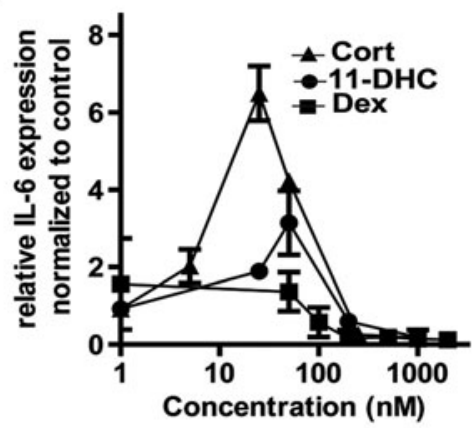

D

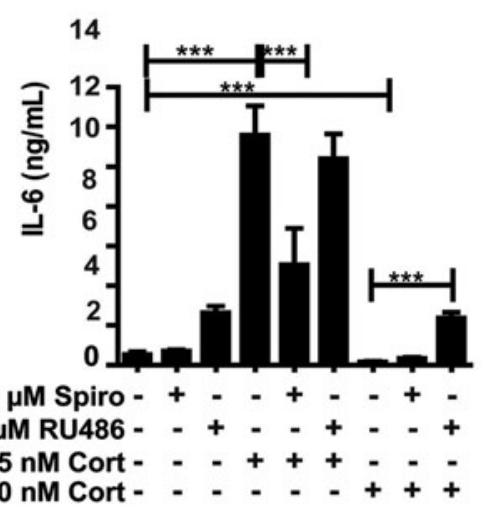

G

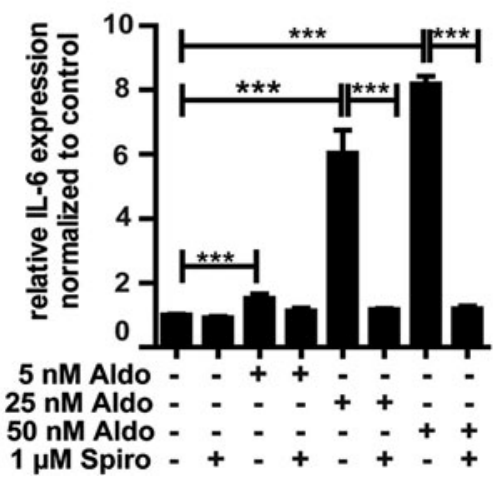

B

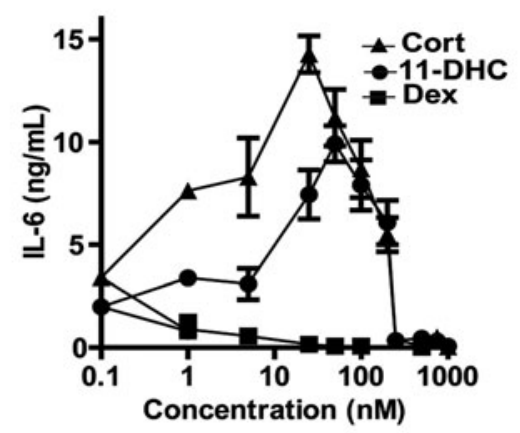

E

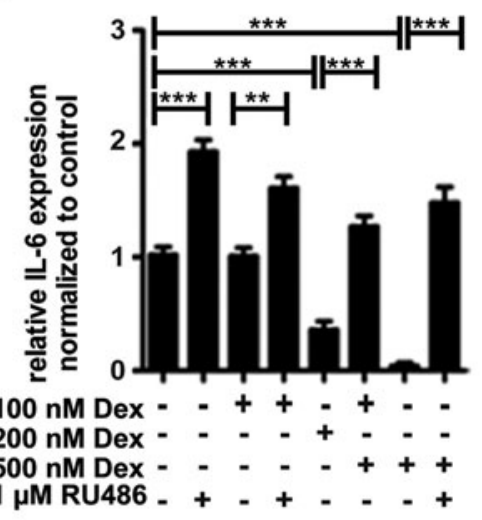

C

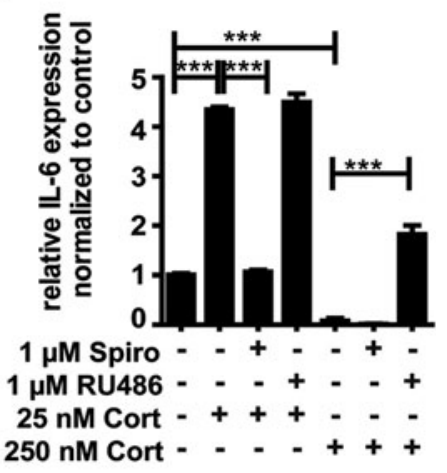

$\mathbf{F}$

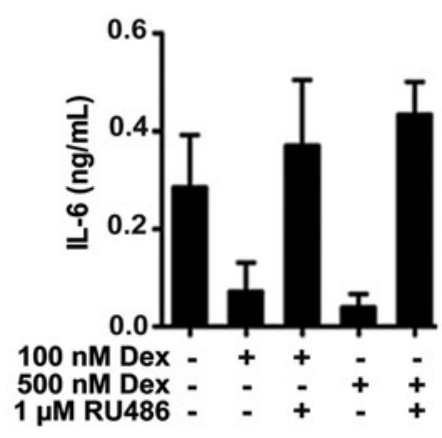

H

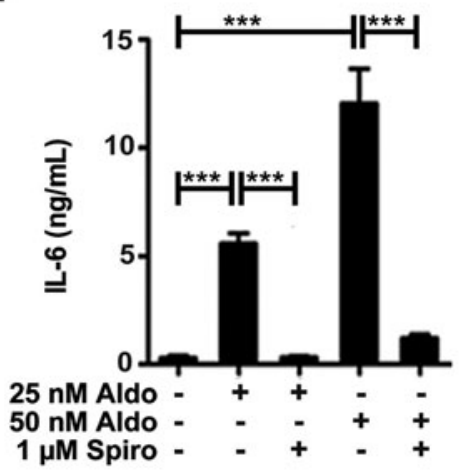

Figure 3 Differential modulation of IL-6 expression by MR and GR. BV-2 cells were treated with various concentrations of 11dehydrocorticosterone $(\mathbf{A}, \mathbf{B})$, corticosterone $(\mathbf{A}-\mathbf{D})$, dexamethasone $(\mathbf{E}, \mathbf{F})$, or aldosterone $(\mathbf{G}, \mathbf{H})$ in the presence or absence of $1 \mu M$ of $M R$ antagonist spironolactone $(\mathbf{C}, \mathrm{D}, \mathrm{G}, \mathrm{H})$ or $1 \mu \mathrm{M}$ of $\mathrm{GR}$ antagonist RU-486 (C-F) for $24 \mathrm{~h}$, as indicated. (A, C, G, E) Quantification of IL-6 mRNA expression by real-time RT-PCR. Data represent ratios of IL-6 mRNA to GAPDH control mRNA from treated cells normalized to the values obtained from cells incubated with vehicle (DMSO). (B, D, F, H) Quantification of IL-6 protein expression by ELISA. Data represent mean \pm SD from three independent experiments. ${ }^{* *} P<0.01,{ }^{* *} P<0.005$. 
(Figure 2B, also known as Merck-544 [33,34]). The impact of LPS and glucocorticoids on IL-6 protein expression was assessed by ELISA. Increased IL-6 protein was observed upon treatment of cells with LPS, whereby the effect on protein expression was more pronounced than the effect on mRNA levels, suggesting enhanced translation and/or protein stability in addition to enhanced gene expression. Importantly, both preincubation with corticosterone and 11-dehydrocorticosterone further increased IL-6 expression, whereby the effect of the latter was blocked by $11 \beta-H S D 1$ inhibitors (Figure $2 \mathrm{C}$ ). In the absence of LPS, incubation of BV-2 cells with $25 \mathrm{nM}$ corticosterone and $50 \mathrm{nM}$ 11-dehydrocorticosterone both enhanced IL- 6 expression. As expected, the effect of 11-dehydrocorticosterone was abolished by $11 \beta$-HSD1 inhibition.

\section{MR and GR differentially modulate the IL-6 expression}

Since glucocorticoids are known as potent antiinflammatory drugs, we next determined the concentration dependence of IL- 6 expression and compared the effects of 11-dehydrocorticosterone, corticosterone, and dexamethasone. The potent GR agonist dexamethasone suppressed IL-6 mRNA and protein expression in a concentrationdependent manner (Figure 3A, B). Unlike the GR-selective ligand dexamethasone, 11-dehydrocorticosterone (upon conversion to corticosterone by $11 \beta$-HSD1) showed a biphasic response with peak stimulatory effects at about $50 \mathrm{nM}$ and potent suppression at concentrations higher than $250 \mathrm{nM}$. Neither spironolactone nor RU-486 at a concentration of $1 \mu \mathrm{M}$ inhibited 11 $\beta$-HSD1 enzyme activity (measured as conversion of radiolabeled cortisone to cortisol in cell lysates). At $20 \mu \mathrm{M}$, spironolactone showed weak inhibition with $78 \pm 14 \%$ remaining activity, and in the presence of RU-486 remaining activity was $69 \pm 9 \%$, thus excluding that the observed effects of the antagonists on IL-6 expression were due to $11 \beta-H S D 1$ inhibition. A similar bi-phasic response, with maximal stimulation at $25 \mathrm{nM}$, was obtained using corticosterone. The stimulatory effect, but not the suppressive effect, could be prevented by co-treatment with the MR antagonist spironolactone (Figure 3C). The bi-phasic response to corticosterone of IL-6 expression and suppression by spironolactone was confirmed on the protein level using ELISA (Figure 3D). High corticosterone concentrations, that is $250 \mathrm{nM}$, decreased IL-6 protein levels. The GR antagonist RU-486 did not affect the corticosterone-induced stimulation of IL-6 mRNA and protein expression. Importantly, at $250 \mathrm{nM}$ corticosterone, which suppressed IL6 expression, co-incubation with RU-486 caused an increase in IL-6 mRNA and protein expression (Figure 3C, D). This suggests that at higher glucocorticoid concentrations GR prevents MR-mediated activation of IL- 6 production and that GR blockade results in pronounced MR-mediated stimulation of production of pro-inflammatory cytokines. Dexamethasone did not affect IL-6 mRNA expression at $100 \mathrm{nM}$ but resulted in a decrease at higher concentrations (Figure 3E). Interestingly, IL-6 protein production was significantly decreased at $100 \mathrm{nM}$ dexamethasone (Figure 3F), suggesting an inhibition of IL-6 translation or decreased protein stability. The reason for the high concentration of dexamethasone needed to suppress IL-6 expression remains unclear; however, since intact cells were used, an efflux pump may be involved. As expected, spironolactone did not affect the dexamethasonemediated effects (data not shown), whereas they were reversed by RU-486 (Figure 3E, F). Opposite effects were obtained upon incubation of BV-2 cells with the MR ligand aldosterone, which induced IL- 6 mRNA and protein expression, whereby these effects were fully reversed by co-treatment with spironolactone (Figure 3G, H).

\section{Effect of corticosteroids on IL-6 expression is mediated through NF-KB}

Next, we tested whether the stimulation of IL-6 production by low/moderate concentrations of 11-dehydrocorticosterone, corticosterone, and aldosterone is dependent on NF-kB activation. Treatment of cells with the NF- $\kappa B$ translocation inhibitor Cay-10512 diminished the corticosteroid-mediated IL-6 production (Figure 4), suggesting that MR-dependent activation of NF- $k B$ is involved in the stimulation of IL-6 expression. To visualize NF- $\kappa B$ activation, immune-fluorescence staining using antibody against the p65 subunit of NF- $\mathrm{KB}$ was performed. As shown in Figure 5, incubation of cells with $25 \mathrm{nM}$ corticosterone or $25 \mathrm{nM}$ aldosterone enhanced the presence of p65 in the nuclei, whereby the corticosteroid-induced NF- $\mathrm{KB}$ translocation could be prevented by co-treatment with either spironolactone or Cay-10512.

The MR-dependent NF- $\mathrm{KB}$ activation was further analyzed by determination of the distribution of p65 using Cellomics ArrayScan high-content imaging (Figure 6). Incubation with aldosterone enhanced the presence of p65 in the nucleus, an effect that was blocked by spironolactone. In contrast, incubation with dexamethasone diminished the presence of p65 in the nucleus, and co-incubation with the GR antagonist RU-486 prevented this effect. The subcellular distribution of p65 was further assessed by western blot analysis of cytoplasmic and nuclear fractions of BV-2 cells. Incubation of cells in the presence of corticosterone or aldosterone led to elevated amounts of the phosphorylated form of p65 in the nucleus, an effect that was prevented by co-treatment with spironolactone (Figure 7A) or Cay-10512 (Figure 7B). 

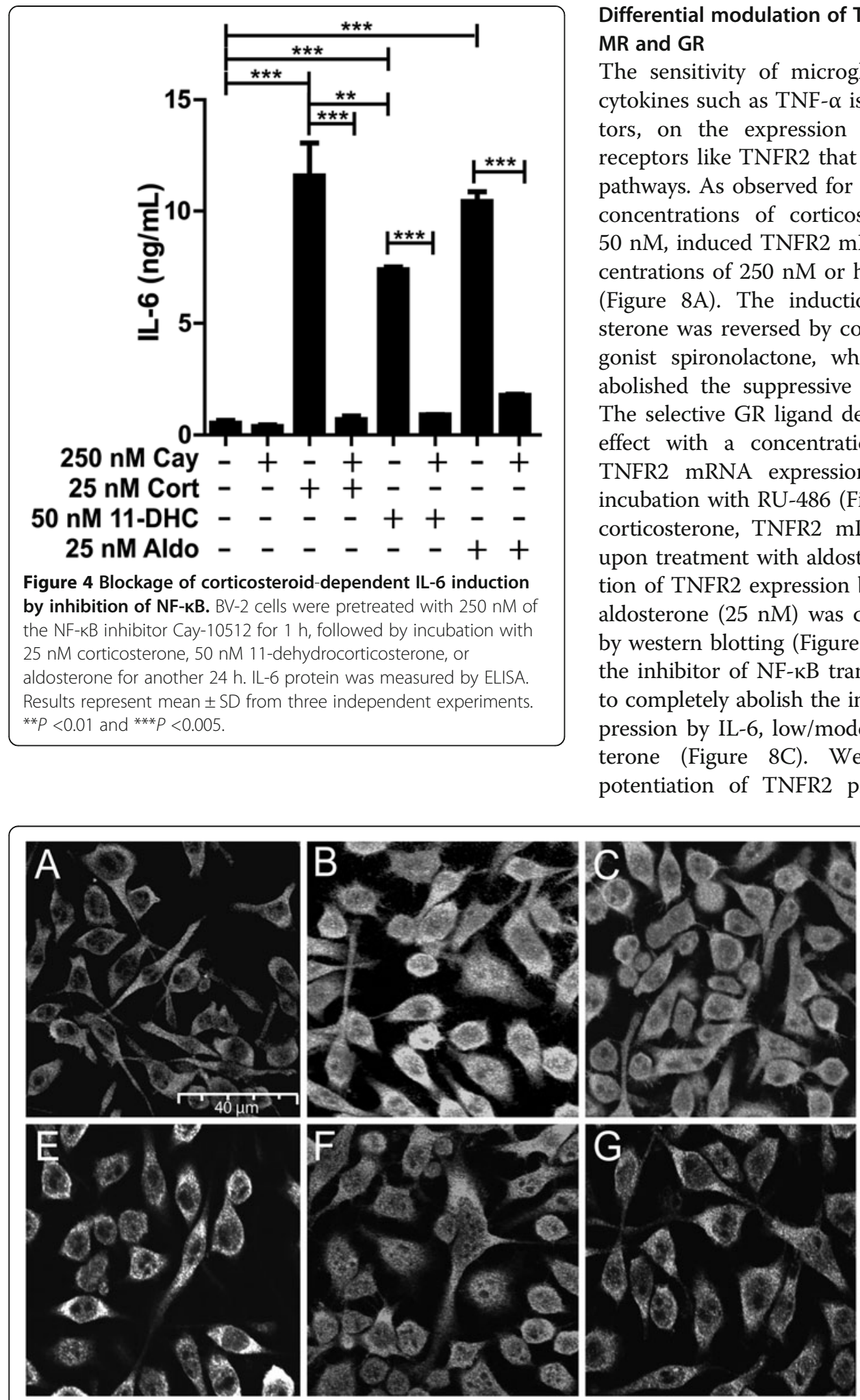

Differential modulation of TNFR2 expression by MR and GR

The sensitivity of microglia cells to pro-inflammatory cytokines such as TNF- $\alpha$ is dependent, among other factors, on the expression levels of membrane surface receptors like TNFR2 that control intracellular signaling pathways. As observed for IL-6 expression, low/moderate concentrations of corticosterone, that is $25 \mathrm{nM}$ and $50 \mathrm{nM}$, induced TNFR2 mRNA expression but high concentrations of $250 \mathrm{nM}$ or higher decreased its expression (Figure 8A). The induction by low/moderate corticosterone was reversed by co-treatment with the MR antagonist spironolactone, whereas GR antagonist RU-486 abolished the suppressive effect of high corticosterone. The selective GR ligand dexamethasone had an opposite effect with a concentration-dependent suppression of TNFR2 mRNA expression that was reversed by coincubation with RU-486 (Figure 8B). As observed for low corticosterone, TNFR2 mRNA expression was induced upon treatment with aldosterone (Figure 8C). The induction of TNFR2 expression by corticosterone ( $50 \mathrm{nM})$ and aldosterone $(25 \mathrm{nM})$ was confirmed on the protein level by western blotting (Figure 8D). Moreover, we found that the inhibitor of NF-KB translocation Cay-10512 was able to completely abolish the induction of TNFR2 mRNA expression by IL-6, low/moderate glucocorticoids or aldosterone (Figure 8C). Western blotting revealed the potentiation of TNFR2 protein expression by $50 \mathrm{nM}$

Figure 5 Corticosterone- and aldosterone-mediated NF-KB translocation is dependent on MR. BV-2 cells were treated for $24 \mathrm{~h}$ with vehicle (A), $50 \mathrm{ng} / \mathrm{mL}$ TNF-a (B), $25 \mathrm{nM}$ corticosterone (C), $25 \mathrm{nM}$ corticosterone and $1 \mu \mathrm{M}$ spironolactone (D), $25 \mathrm{nM}$ corticosterone and $250 \mathrm{nM}$ Cay-10512 (E), $50 \mathrm{nM}$ aldosterone (F), $50 \mathrm{nM}$ aldosterone and $1 \mu \mathrm{M}$ spironolactone (G), or $50 \mathrm{nM}$ aldosterone and $250 \mathrm{nM}$ Cay-10512 (H). The localization of the p65 subunit of NF-KB was visualized by immunofluorescence microscopy using a primary antibody against p65 and a secondary ALEXA fluor 488 labeled antibody (magnification 400X). 


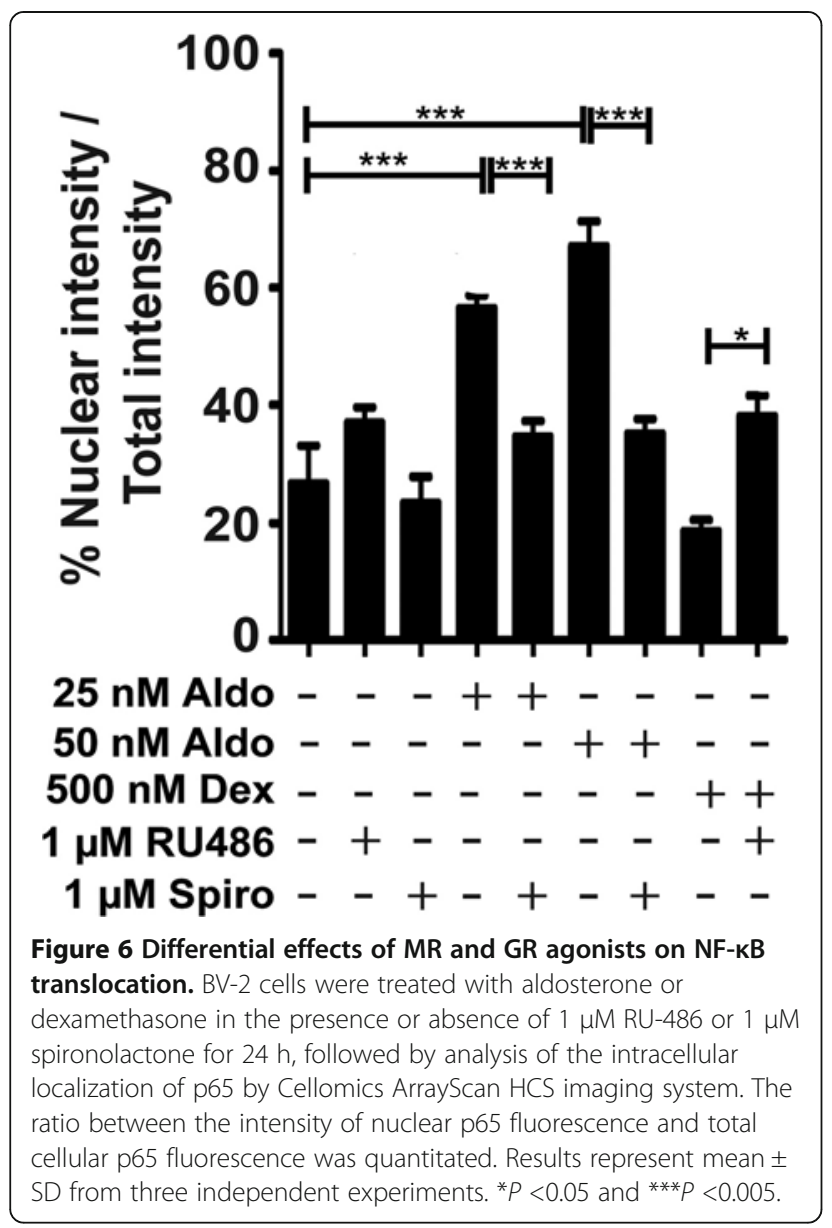

corticosterone and $50 \mathrm{nM}$ aldosterone, and further demonstrated the requirement of NF- $\mathrm{kB}$ activation for this induction (Figure 8E). 11-dehydrocorticosterone similarly induced TNFR2 expression, which was prevented by inhibition of $11 \beta$-HSD1 (Figure 8F).
IL-6 and low glucocorticoids synergistically increased $11 \beta-H S D 1$ mRNA expression and reductase activity

Glucocorticoids showed a bi-phasic effect on the production of pro-inflammatory cytokines, depending on activation of MR only, at low concentrations, or both $\mathrm{MR}$ and GR at higher concentrations. Thus, an elevation of the intracellular concentration of active glucocorticoids by $11 \beta$-HSD1 may play an important role in the resolution of inflammation by causing a shift from MRto GR-mediated regulation of pro-inflammatory cytokine expression. As shown in Figure 9, incubation of BV-2 cells with $20 \mathrm{ng} / \mathrm{mL}$ of IL-6 resulted in increased $11 \beta$ HSD1 mRNA expression, which was strongly enhanced by co-incubation with $50 \mathrm{nM}$ 11-dehydrocorticosterone. Pharmacological inhibition of $11 \beta-H S D 1$ prevented the effects of 11-dehydrocorticosterone. To test whether incubation with IL-6 would enhance $11 \beta$-HSD1 enzyme activity, we measured the conversion of radiolabeled cortisone to cortisol. Due to technical reasons cortisone instead of 11-dehydrocorticosterone was used to study the effect on enzyme activity. Both IL-6 and cortisone resulted in increased $11 \beta$-HSD1 reductase activity, which was strongly enhanced by co-incubation with IL-6 and cortisone (data not shown), indicating that the changes observed on the mRNA level are translated to enzyme activity.

Interestingly, while low corticosterone in the absence of IL-6 showed weak stimulatory effects on $11 \beta$-HSD1 expression, higher concentrations resulted in a more pronounced induction of expression (Figure 10). Spironolactone and RU-486 both were able to block the induction of $11 \beta$-HSD1 expression. Both, treatment of cells with aldosterone and dexamethasone enhanced $11 \beta$-HSD1 mRNA expression. Together with the fact that low and high glucocorticoid concentrations led to increased $11 \beta$-HSD1 expression, the results suggest a feed-forward regulation including both MR and GR.

\section{A}

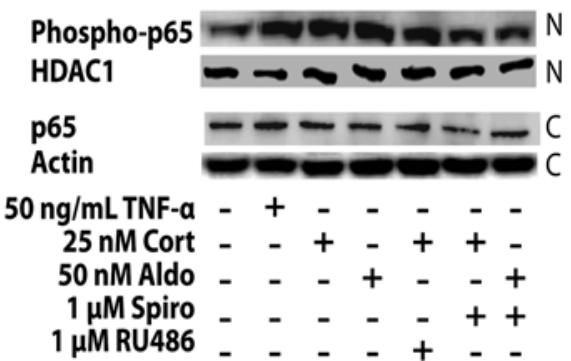

\section{B}

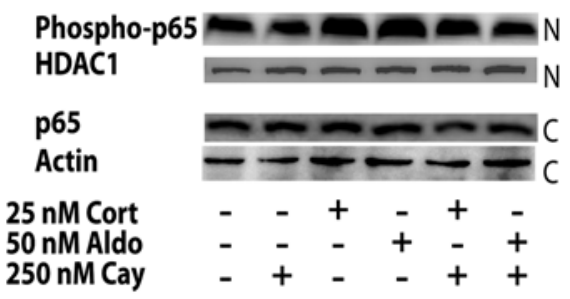

Figure 7 Nuclear - cytoplasmic distribution of NF-кB p65 determined by western blotting. BV-2 cells were treated for 24 h with 50 ng/mL TNF-a, $25 \mathrm{nM}$ corticosterone, or $50 \mathrm{nM}$ aldosterone in the absence or presence of $1 \mu \mathrm{M}$ spironolactone or $1 \mu \mathrm{M}$ RU-486 (A), or in the presence of 250 nM Cay-10512 (B), followed by preparation of nuclear and cytoplasmic fractions, separation of proteins by SDS-PAGE and analysis of p65 and phospho-p65 expression by western blotting. Actin served as a loading control. A representative blot from three independent experiments is shown. 


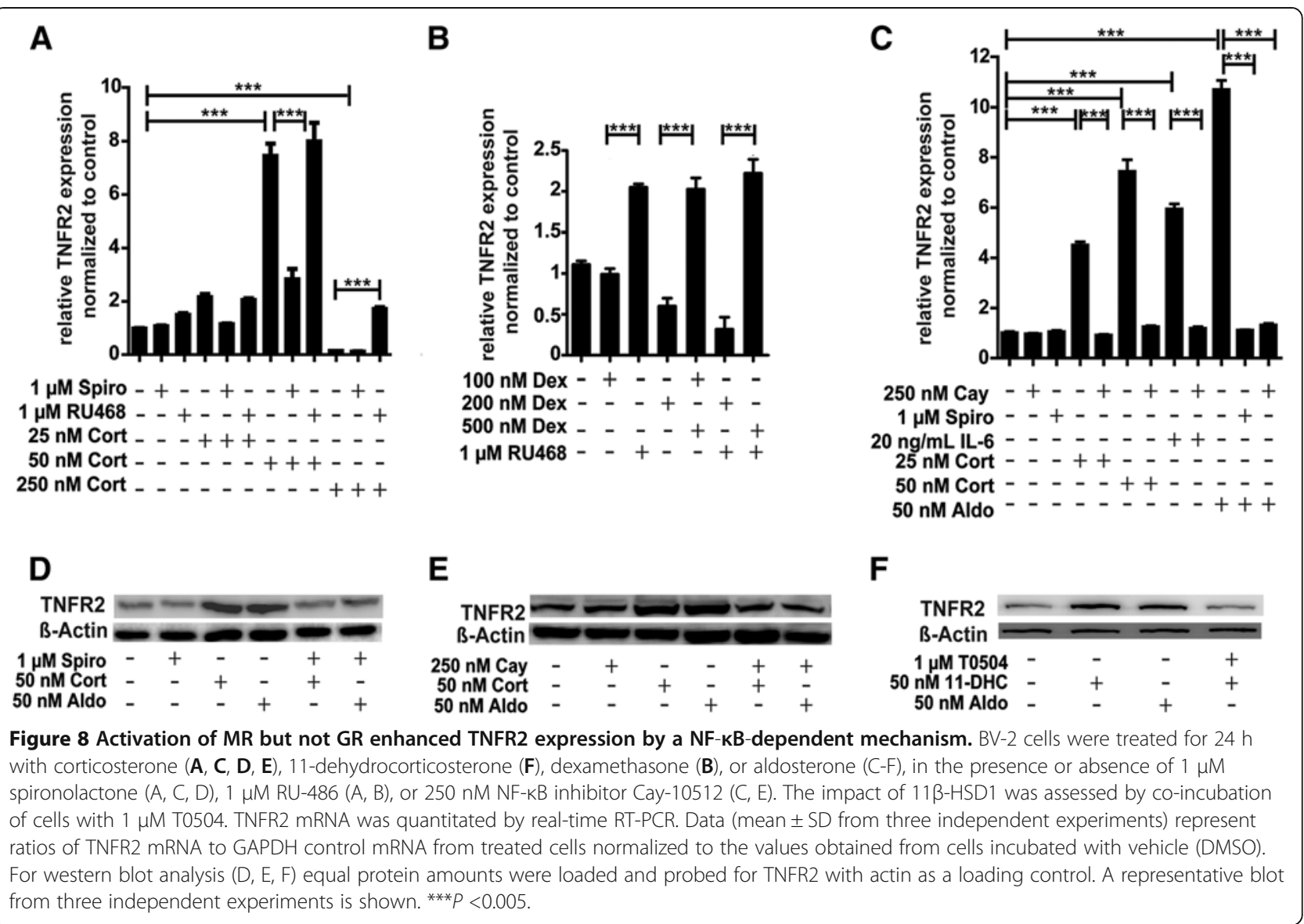

\section{Discussion}

A recent comparison of the murine BV-2 cell line with primary mouse microglia cells revealed highly overlapping gene expression profiles upon stimulation with LPS, although the response in BV-2 was generally less pronounced [25]. Approximately $90 \%$ of the genes induced by LPS in BV-2 cells were also induced in primary microglia, and $50 \%$ of the genes were also affected in hippocampal microglia following in-vivo stimulation of mice by intracerebroventricular LPS injection. These observations indicate that the BV-2 cell line is a suitable model of murine microglia to study neuroinflammatory parameters.

In the present study, we employed BV-2 cells as a macrophage/microglia cell model to characterize the impact of endogenous and synthetic corticosteroids on NF$\mathrm{KB}$ activation and on IL-6 and TNFR2 expression. We found that BV-2 cells functionally express MR, GR, and $11 \beta-H S D 1$, and our results emphasize the importance of a well-balanced activity of MR, which stimulates proinflammatory mediators, and GR that counteracts these effects. The selective MR ligand aldosterone exclusively resulted in NF- $\mathrm{kB}$ activation and upregulation of IL-6 and TNFR2 expression, whereas the selective GR ligand dexamethasone had opposite effects. The concentration of aldosterone to activate MR in BV-2 cells was approximately one order of magnitude higher than anticipated based on its $\mathrm{K}_{\mathrm{d}}$ of about $0.5 \mathrm{nM}$. The effect on IL- 6 protein levels was more pronounced than that on mRNA expression, indicating increased translation and/or protein stability. Similar observations were made using dexamethasone, for which $K_{d}$ values for GR of 3-4 nM have been reported [5,35]. While $100 \mathrm{nM}$ dexamethasone readily suppressed IL-6 protein it had no effect on mRNA expression. As a possible explanation an efflux pump expressed in BV-2 cells may lower the actual intracellular concentration of aldosterone and dexamethasone.

Corticosterone and 11-dehydrocorticosterone (upon conversion to corticosterone by $11 \beta-H S D 1$ ) stimulated the expression of IL- 6 and TNFR2 and activated NF- $\mathrm{kB}$ at low/moderate concentrations by acting through MR, whereas higher concentrations exerted suppressive effects by acting through GR. Over $95 \%$ of the circulating corticosterone is bound to transcortin and albumin. Under normal conditions peak corticosterone concentrations in mice and rats in the unstressed state range between $250 \mathrm{nM}$ and $500 \mathrm{nM}$, thus assuming that the free fraction in plasma reaches concentrations up to $25 \mathrm{nM}$. 


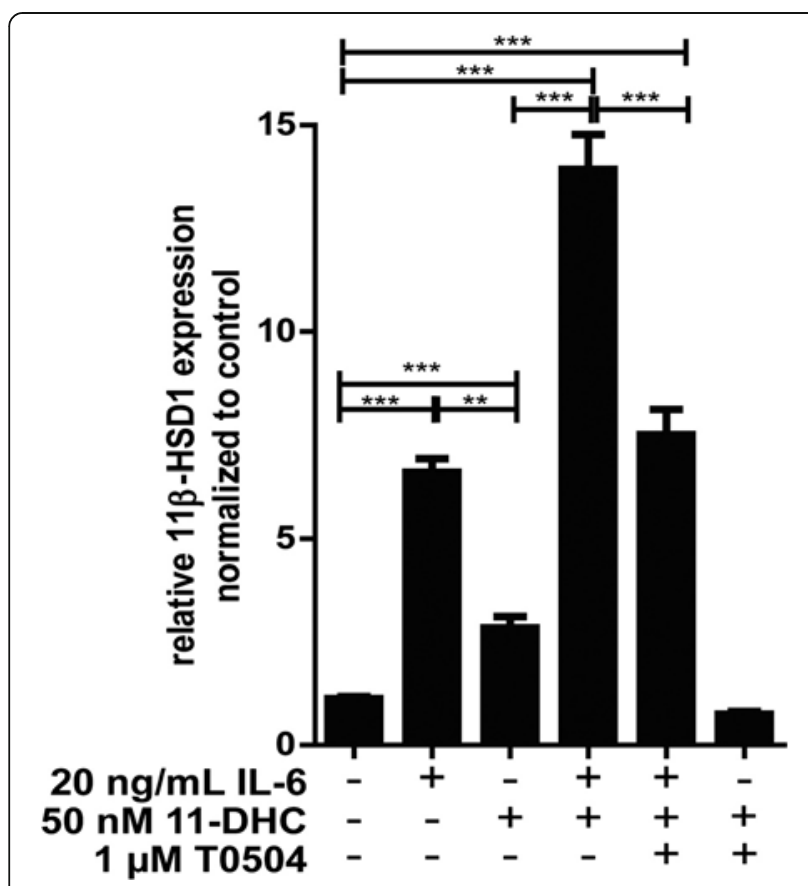

Figure 9 Potentiation of the IL-6-dependent increase of $11 \beta$-HSD1 mRNA expression by low concentrations of 11-dehydrocorticosterone. BV-cells were pretreated with $1 \mu \mathrm{M} 11 \beta$-HSD 1 inhibitor T0504 where indicated for $1 \mathrm{~h}$, followed by addition of $50 \mathrm{nM} 11$-dehydrocorticosterone with or without $20 \mathrm{ng} / \mathrm{mL} \mathrm{IL}-6$ and incubation for another $24 \mathrm{~h} .11 \beta-H S D 1$ mRNA was determined by real-time RT-PCR. Data (mean \pm SD from three independent experiments) represent ratios of $11 \beta-H S D 1$ mRNA to GAPDH control mRNA from treated cells normalized to the values obtained from cells incubated with vehicle (DMSO). ${ }^{* *} P<0.01$, ***P $<0.005$
The intracellular concentrations may differ significantly from this value depending on uptake and 11/-HSDdependent metabolism. In the presented experiments, we used $25 \mathrm{nM}$ as a low and $250 \mathrm{nM}$ as a high corticosterone concentration in culture medium containing $10 \%$ FBS. Despite the reduced amount of serum proteins present in the culture medium, the capacity should be sufficient to bind most of the $25 \mathrm{nM}$ corticosterone added, probably resulting in a free steroid concentration below $2 \mathrm{nM}$. Nevertheless, the MR with a $K_{d}$ of $0.5 \mathrm{nM}$ for corticosterone is expected to be occupied, whereas the GR with a $K_{d}$ of 5 to $10 \mathrm{nM}$ is probably not activated, thus reflecting the situation under normal physiological conditions. In contrast, at $250 \mathrm{nM}$ the binding capacity of the FBS present in the culture medium is probably saturated, resulting in high unbound corticosterone levels, reflecting levels reached during stress conditions and leading to occupation of GR.

Upon further increasing corticosterone from concentrations needed for maximal induction of IL-6 expression, a rapid decline was observed (Figure 3A, B). This may be explained by the higher expression levels of GR compared with MR, suggesting that occupation of few GR molecules may be sufficient to suppress MR activity. It is not clear at present whether GR suppresses MR function by competing for coactivators/corepressors, by competing for binding sites on the promoter of a given target gene, or by formation of heterodimers. Interestingly, RU-486 enhanced IL-6 and TNFR2 expression in the absence of added steroids (Figure 3E, Figure 8B). In preliminary experiments using transfected cells, we observed ligand-independent MR activity that was lowered upon co-expressing GR. RU-486 might act as an inverse agonist and induce a conformational change upon binding to GR, which may prevent heterodimer
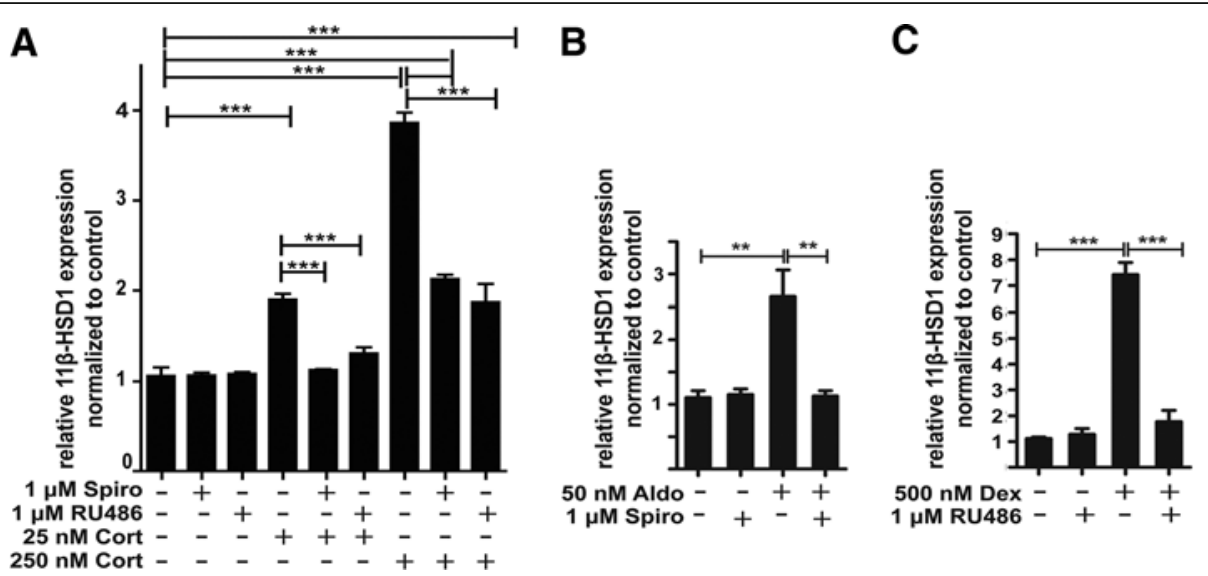

Figure $1011 \beta-H S D 1$ mRNA expression is enhanced by both MR and GR activation. BV-2 cells were treated for $24 \mathrm{~h}$ with corticosterone (A), aldosterone $(\mathbf{B})$, or dexamethasone $(\mathbf{C})$ in the presence or absence of $1 \mu \mathrm{M}$ spironolactone (A, B) or $1 \mu \mathrm{M}$ RU-486 (A, C). $11 \beta-H S D 1$ mRNA was quantitated by real-time RT-PCR. Data (mean \pm SD from three independent experiments) represent ratios of 11 $\beta$-HSD1 mRNA to GAPDH control mRNA from treated cells normalized to the values obtained from cells incubated with vehicle (DMSO). ${ }^{* *} P<0.01,{ }^{* * *} P<0.005$. 
formation or, alternatively, GR may compete with MR for a corepressor protein, thereby increasing $M R$ activity.

Nevertheless, the results suggest a tightly controlled and coordinated action of $\mathrm{MR}$ and GR in the regulation of NF- $\mathrm{KB}$ activity and the production of and sensitivity to pro-inflammatory cytokines in microglia cells. Proinflammatory cytokines such as TNF- $\alpha$, IL-1 $\beta$, and IL-6, and subsequent activation of NF- $\mathrm{kB}$, lead to elevated expression and activity of $11 \beta-H S D 1$, which results in enhanced local levels of active glucocorticoids (this study, and [18]). The fact that both GR and MR promote $11 \beta$-HSD1 expression may represent an important feedforward regulation of glucocorticoid activation in order to increase the intracellular concentration of active glucocorticoids and to shift the balance from an initially predominantly MR-mediated stimulation to a GR-mediated suppression of inflammation. The enhanced local glucocorticoid activation may be necessary for the resolution of inflammation. The suppression of pro-inflammatory cytokines and NF- $k B$ activity upon activation of GR should then allow normalization of $11 \beta-H S D 1$ expression and activity.

Evidence for a stimulation of inflammatory parameters by low to moderate glucocorticoid concentrations was also obtained from recent experiments with murine 3 T3-L1 adipocytes [1]. Decreased adiponectin mRNA and increased IL- 6 mRNA were observed upon incubation of 3 T3-L1 adipocytes with $100 \mathrm{nM}$ corticosterone or cortisol. These effects were partially reversed by treatment with the MR antagonist eplerenone but not by GR antagonist RU486, suggesting that MR activation was responsible for the observed effects. Furthermore, $100 \mathrm{nM}$ of the glucocorticoids increased NADPH oxidase subunit p22 mRNA levels and decreased catalase mRNA levels, which were reversed by co-treatment with eplerenone. However, the authors did not test the effects of various concentrations, nor was the role of $11 \beta$-HSD1 addressed.

Other investigators observed elevated 11ß-HSD1 mRNA and activity in 3 T3-L1 adipocytes that were treated with LPS, TNF- $\alpha$, or IL-1 $\beta$ [2]. Pharmacological inhibition of $11 \beta-H S D 1$ diminished the TNF- $\alpha$-induced activation of NF-kB and MAPK signaling. Their study, however, did not assess the role of MR and the impact of higher glucocorticoid concentrations. At high glucocorticoid levels, pharmacological inhibition of $11 \beta-H S D 1$ might abolish GR activation, thereby promoting MRmediated pro-inflammatory effects. Since actual glucocorticoid concentrations in intact microglia cannot be measured, it will be important to assess the effects of $11 \beta$-HSD1 inhibitors on neuroinflammation in vivo in future studies. Nevertheless, these observations are in line with our findings in microglia cells that low/moderate glucocorticoid concentrations mainly act through MR, thereby promoting inflammatory parameters.

During acute inflammation, TNF- $\alpha$ acts through membrane-bound TNF-receptors on macrophage and microglial cells, leading to activation of transcription factors such as NF- $\mathrm{KB}$ and AP1, which can induce a second wave of pro-inflammatory cytokines, including TNF- $\alpha$, IL-1 $\beta$ and IL-6. TNFR2 is highly expressed on microglia cells and plays an important role in the regulation of innate immune response following brain injury on infection [36]. An elevated expression of TNFR2 upon MR activation, as observed in the present study, is expected to result in a higher sensitivity and more pronounced response to external pro-inflammatory stimuli.

Disruption of MR- and GR-mediated regulation of gene transcription and interaction with other transcription factors can occur at several levels. Reduced GR activity and/or enhanced MR activity, thus exacerbating inflammation, may be caused by the presence of xenobiotics differentially modulating receptor activity, posttranslational receptor modifications, altered function of receptor-associated proteins, or altered protein stability

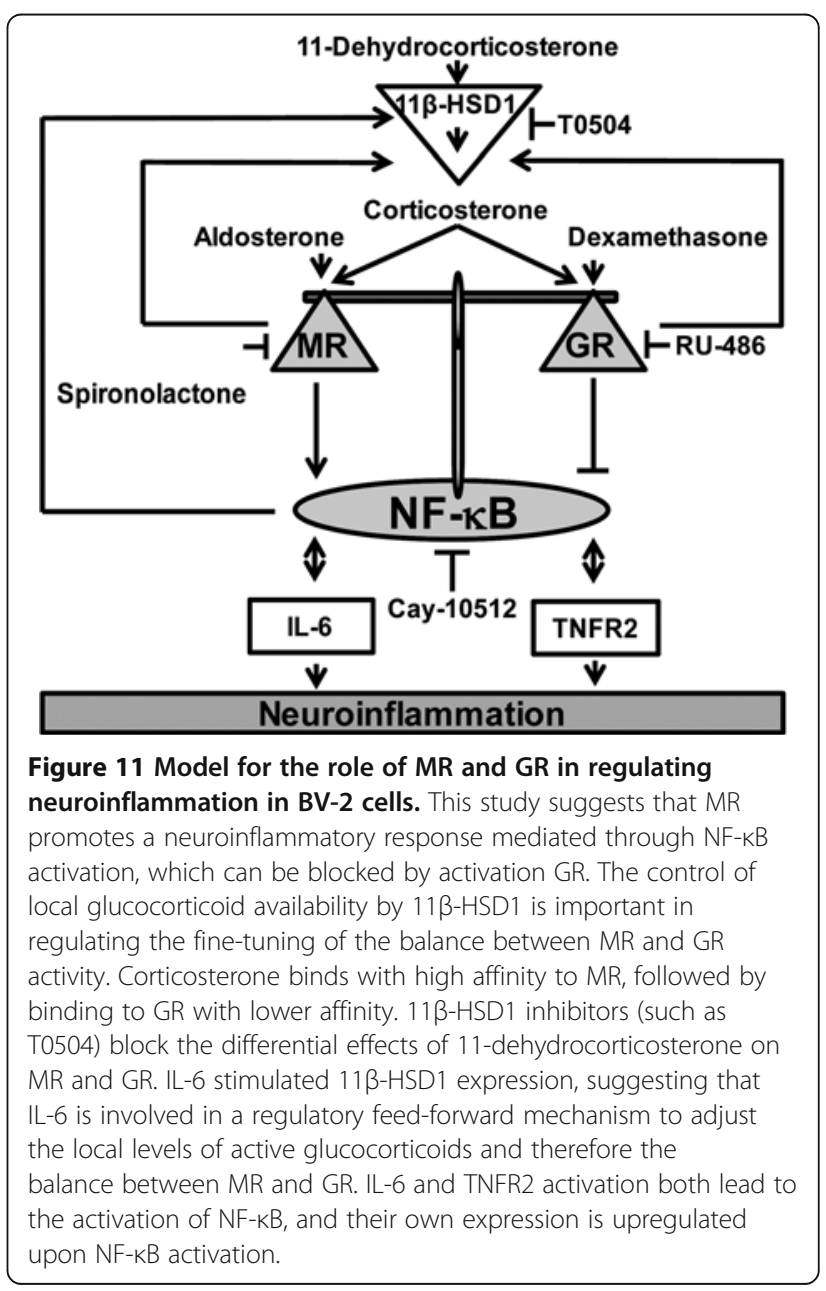


[30]. The pro-inflammatory cytokines TNF- $\alpha$, IL-1 $\beta$, and IL-6 were shown to activate the HPA axis [37], thereby enhancing circulating glucocorticoids and exerting suppressive effects through GR activation. However, high levels of TNF- $\alpha$ have been associated with glucocorticoid resistance [38]. Upon excessive HPA activation, a downregulation of GR activity, probably caused by altered phosphorylation of the receptor and reduced protein stability [38,39], with concomitant glucocorticoid resistance has been observed, which may cause a shift from GR- to MR-mediated glucocorticoid effects. GR blockade by administration of RU486 or elimination of glucocorticoids by adrenalectomy sensitized C57BL/6 mice to low-dose TNF- $\alpha$ [38]. Moreover, hepatic GR-deficient mice showed significantly higher levels of IL- 6 in response to TNF- $\alpha$ treatment.

Glucocorticoid-resistance represents a major problem in chronic inflammation, including rheumatoid arthritis, ulcerative colitis, Crohn's disease, atherosclerosis, cystic fibrosis, and chronic obstructive pulmonary disease [40]. An impaired suppression by GR may lead to chronically enhanced MR activity. It remains to be investigated whether MR antagonists may prove beneficial in these diseases.

Increasing evidence indicates that neuroinflammation contributes to neuronal degeneration and the progression of Parkinson's disease [41,42]. Activated microglial cells and increased expression of pro-inflammatory mediators have been found in the substantia nigra of patients. Interestingly, elevated circulating cortisol levels were measured in Parkinson's disease patients together with decreased GR expression in the substantia nigra [43]. Selective ablation of GR in macrophage/microglia exacerbated the loss of dopaminergic neurons induced by 1-methyl-4-phenyl-1,2,3,6-tetrahydropyridine (MPTP), enhanced the production of pro-inflammatory parameters, and diminished the expression of anti-inflammatory mediators. Based on the findings of the present study, we hypothesize that the potentiation of neuroinflammation in GR-deficient states is due to an impaired balance of pro- and anti-inflammatory mediators as a result of a dysbalance of MR and GR activity. The role of MR in Parkinson's disease and whether MR antagonists may prove useful in the treatment of this disease remain to be investigated.

\section{Conclusions}

BV-2 cells represent a suitable microglia cell model for studying effects of endogenous and synthetic corticosteroids on inflammatory parameters (Figure 11). These cells co-express MR and GR, which differentially modulate NF- $\mathrm{kB}$ activity, the production of pro-inflammatory cytokines and membrane-surface receptors involved in the sensitivity to TNF- $\alpha$. The availability of active endogenous glucocorticoids in these cells is tightly controlled by $11 \beta$-HSD1, whose expression and activity is induced by pro-inflammatory cytokines and subsequent NF- $\mathrm{kB}$ activation. By enhancing intracellular concentrations of active glucocorticoids, $11 \beta$-HSD1 impacts on the balanced regulation of MR- and GR-mediated responses and may play a crucial role in resolution of inflammation. Impaired function of each of the three proteins is expected to cause disturbed inflammation.

\section{Additional file}

Additional file 1: Table S1. Real-time PCR primers.

\section{Abbreviations}

11ß-HSD1: 11ß-hydroxysteroid dehydrogenase 1; BCA: Bicinchoninic acid; DEPC: Diethyl pyrocarbonate; DMEM: Dulbecco's Modified Eagle Medium; DMSO: Dimethyl sulfoxide; DTT: Dithiothreitol; ELISA: Enzyme-linked immunosorbent assay; FBS: Fetal bovine serum; GAPDH: Glyceraldehyde 3-phosphate dehydrogenase; GR: Glucocorticoid receptor; HCS: High-content screening; HDAC-1: Histone deacetylase 1; HEPES: 4-(2-hydroxyethyl)1-piperazineethanesulfonic acid; HRP: Horseradish peroxidase; IL-6: Interleukin-6; LPS: Lipopolysacharide; MR: Mineralocorticoid receptor; NF-kB: Nuclear factor kappa-light-chain-enhancer of activated B cells; PBS: Phosphate buffered saline; PVDF: Polyvinylidene difluoride; SDS-PAGE: Sodium dodecyl sulfate polyacrylamide gel electrophoresis; TNF-a: Tumor necrosis factor-alpha; TNFR2: Tumor necrosis factor receptor 2.

\section{Competing interests}

The authors declare that they have no competing interests.

\section{Authors' contribution}

$\mathrm{BC}$ and $\mathrm{AO}$ designed the study. BC performed the experiments and analyzed the data. DK, LN, and ZB helped planning experiments and analyzing the data. BC, DK, and AO wrote the manuscript. All authors read and approved the final manuscript.

\section{Acknowledgements}

This work was supported by the Swiss National Science Foundation (31003A-140961 and 316030-133859). AO has a Chair for Molecular and Systems Toxicology by the Novartis Research Foundation.

Received: 12 June 2012 Accepted: 14 November 2012 Published: 28 November 2012

\section{References}

1. Hirata A, Maeda N, Nakatsuji H, Hiuge-Shimizu A, Okada T, Funahashi T, Shimomura I: Contribution of glucocorticoid-mineralocorticoid receptor pathway on the obesity-related adipocyte dysfunction. Biochem Biophys Res Commun 2012, 419:182-187.

2. Ishii-Yonemoto T, Masuzaki H, Yasue S, Okada S, Kozuka C, Tanaka T, Noguchi M, Tomita T, Fujikura J, Yamamoto Y, Ebihara K, Hosoda K, Nakao K: Glucocorticoid reamplification within cells intensifies NF-kappaB and MAPK signaling and reinforces inflammation in activated preadipocytes. Am J Physiol Endocrinol Metab 2010, 298:E930-E940.

3. Marzolla V, Armani A, Zennaro MC, Cinti F, Mammi C, Fabbri A, Rosano GM, Caprio M: The role of the mineralocorticoid receptor in adipocyte biology and fat metabolism. Mol Cell Endocrinol 2012, 350:281-288.

4. De Kloet ER, Vreugdenhil E, Oitzl MS, Joels M: Brain corticosteroid receptor balance in health and disease. Endocr Rev 1998, 19:269-301.

5. De Kloet ER, Veldhuis HD, Wagenaars JL, Bergink EW: Relative binding affinity of steroids for the corticosterone receptor system in rat hippocampus. J Steroid Biochem Mol Biol 1984, 21:173-178.

6. Reul JM, de Kloet ER: Two receptor systems for corticosterone in rat brain: microdistribution and differential occupation. Endocrinology 1985, 117:2505-2511. 
7. Reul JM, van den Bosch FR, de Kloet ER: Relative occupation of type-I and type-Il corticosteroid receptors in rat brain following stress and dexamethasone treatment: functional implications. J Endocrinol 1987, 115:459-467.

8. Sapolsky RM, Romero LM, Munck AU: How do glucocorticoids influence stress responses? Integrating permissive, suppressive, stimulatory, and preparative actions. Endocr Rev 2000, 21:55-89.

9. Funder JW: Mineralocorticoid receptors in the central nervous system. J Steroid Biochem Mol Biol 1996, 56:179-183.

10. Cintra A, Bhatnagar M, Chadi G, Tinner B, Lindberg J, Gustafsson JA, Agnati LF, Fuxe K: Glial and neuronal glucocorticoid receptor immunoreactive cell populations in developing, adult, and aging brain. Ann N Y Acad Sci U S A 1994, 746:42-61.

11. Odermatt A, Kratschmar DV: Tissue-specific modulation of mineralocorticoid receptor function by 11 beta-hydroxysteroid dehydrogenases: an overview. Mol Cell Endocrinol 2012, 350:168-186.

12. Edwards CR, Stewart PM, Burt D, Brett L, McIntyre MA, Sutanto WS, de Kloet ER, Monder C: Localisation of 11 beta-hydroxysteroid dehydrogenase-tissue specific protector of the mineralocorticoid receptor. Lancet 1988, 2:986-989.

13. Funder JW, Pearce PT, Smith $\mathrm{R}$, Smith Al: Mineralocorticoid action: target tissue specificity is enzyme, not receptor, mediated. Science 1988 242:583-585.

14. Odermatt A, Arnold P, Frey FJ: The intracellular localization of the mineralocorticoid receptor is regulated by 11 beta-hydroxysteroid dehydrogenase type 2. J Biol Chem 2001, 276:28484-28492.

15. Ferrari $P$ : The role of 11 beta-hydroxysteroid dehydrogenase type 2 in human hypertension. Biochim Biophys Acta 2010, 1802:1178-1187.

16. Frey FJ, Odermatt A, Frey BM: Glucocorticoid-mediated mineralocorticoid receptor activation and hypertension. Curr Opin Nephrol Hypertens 2004, 13:451-458.

17. Mune T, Rogerson FM, Nikkila H, Agarwal AK, White PC: Human hypertension caused by mutations in the kidney isozyme of 11 beta-hydroxysteroid dehydrogenase. Nat Genet 1995, 10:394-399.

18. Tischner D, Reichardt HM: Glucocorticoids in the control of neuroinflammation. Mol Cell Endocrinol 2007, 275:62-70.

19. Barnes PJ: Glucocorticosteroids: current and future directions. Br J Pharmacol 2011, 163:29-43.

20. de Kloet ER, Van Acker SA, Sibug RM, Oitzl MS, Meijer OC, Rahmouni K, de Jong W: Brain mineralocorticoid receptors and centrally regulated functions. Kidney Int 2000, 57:1329-1336.

21. Hugin-Flores ME, Steimer T, Aubert ML, Schulz P: Mineralo- and glucocorticoid receptor mrnas are differently regulated by corticosterone in the rat hippocampus and anterior pituitary. Neuroendocrinology 2004, 79:174-184.

22. Groeneweg FL, Karst H, de Kloet ER, Joels M: Mineralocorticoid and glucocorticoid receptors at the neuronal membrane, regulators of nongenomic corticosteroid signalling. Mol Cell Endocrinol 2012, 350:299-309.

23. Gottfried-Blackmore A, Sierra A, McEwen BS, Ge R, Bulloch K: Microglia express functional 11 beta-hydroxysteroid dehydrogenase type 1 . Glia 2010, 58:1257-1266.

24. Funder JW: Aldosterone and mineralocorticoid receptors: a personal reflection. Mol Cell Endocrinol 2012, 350:146-150.

25. Henn A, Lund S, Hedtjarn M, Schrattenholz A, Porzgen P, Leist M: The suitability of BV2 cells as alternative model system for primary microglia cultures or for animal experiments examining brain inflammation. ALTEX 2009, 26:83-94.

26. Bocchini V, Mazzolla R, Barluzzi R, Blasi E, Sick P, Kettenmann H: An immortalized cell line expresses properties of activated microglial cells. J Neurosci Res 1992, 31:616-621.

27. Blasi E, Barluzzi R, Bocchini V, Mazzolla R, Bistoni F: Immortalization of murine microglial cells by a v-raf/v-myc carrying retrovirus. J Neuroimmunol 1990, 27:229-237.

28. Livak KJ, Schmittgen TD: Analysis of relative gene expression data using real-time quantitative $P C R$ and the $2(-$ delta delta $C(T))$ method. Methods 2001, 25:402-408.

29. Ding GJ, Fischer PA, Boltz RC, Schmidt JA, Colaianne JJ, Gough A, Rubin RA, Miller DK: Characterization and quantitation of NF-kappaB nuclear translocation induced by interleukin-1 and tumor necrosis factor-alpha. Development and use of a high capacity fluorescence cytometric system. J Biol Chem 1998, 273:28897-28905
30. Odermatt A, Atanasov AG: Mineralocorticoid receptors: emerging complexity and functional diversity. Steroids 2009, 74:163-171.

31. Fiers W, Beyaert R, Brouckaert P, Everaerdt B, Haegeman C, Suffys $P$, Tavernier J, Vanhaesebroeck B: TNF: its potential as an antitumour agent. Dev Biol Stand 1988, 69:143-151.

32. Schuster D, Maurer EM, Laggner C, Nashev LG, Wilckens T, Langer T, Odermatt $A$ : The discovery of new 11 beta-hydroxysteroid dehydrogenase type 1 inhibitors by common feature pharmacophore modeling and virtual screening. J Med Chem 2006, 49:3454-3466.

33. Hermanowski-Vosatka A, Balkovec JM, Cheng K, Chen HY, Hernandez M, Koo GC, Le Grand CB, Li Z, Metzger JM, Mundt SS, Noonan H, Nunes CN, Olson SH, Pikounis B, Ren N, Robertson N, Schaeffer JM, Shah K, Springer MS, Strack AM, Strowski M, Wu K, Wu T, Xiao J, Zhang BB, Wright SD, Thieringer R: 11 beta-HSD1 inhibition ameliorates metabolic syndrome and prevents progression of atherosclerosis in mice. J Exp Med 2005, 202:517-527.

34. Arampatzis S, Kadereit B, Schuster D, Balazs Z, Schweizer RA, Frey FJ, Langer T, Odermatt A: Comparative enzymology of 11 beta-hydroxysteroid dehydrogenase type 1 from six species. J Mol Endocrinol 2005, 35:89-101.

35. Rebuffat AG, Tam S, Nawrocki AR, Baker ME, Frey BM, Frey FJ, Odermatt A: The 11-ketosteroid 11-ketodexamethasone is a glucocorticoid receptor agonist. Mol Cell Endocrinol 2004, 214:27-37.

36. Veroni C, Gabriele L, Canini I, Castiello L, Coccia E, Remoli ME, Columba-Cabezas S, Arico E, Aloisi F, Agresti C: Activation of TNF receptor 2 in microglia promotes induction of anti-inflammatory pathways. Mol Cell Neurosci 2010, 45:234-244.

37. Chrousos GP: The hypothalamic-pituitary-adrenal axis and immunemediated inflammation. New Engl J Med 1995, 332:1351-1362.

38. Van Bogaert $T$, Vandevyver $S$, Dejager $L$, Van Hauwermeiren F, Pinheiro I, Petta I, Engblom D, Kleyman A, Schutz G, Tuckermann J, Libert C: Tumor necrosis factor inhibits glucocorticoid receptor function in mice: a strong signal toward lethal shock. J Biol Chem 2011, 286:26555-26567.

39. Van Bogaert T, De Bosscher K, Libert C: Crosstalk between TNF and glucocorticoid receptor signaling pathways. Cytokine Growth F R 2010, 21:275-286.

40. Barnes PJ, Adcock IM: Glucocorticoid resistance in inflammatory diseases. Lancet 2009, 373:1905-1917.

41. Hirsch EC, Hunot S: Neuroinflammation in Parkinson's disease: a target for neuroprotection? Lancet Neurol 2009, 8:382-397.

42. Hirsch EC, Vyas S, Hunot S: Neuroinflammation in Parkinson's disease. Parkinsonism Relat Disord 2012, 1:S210-S212.

43. Ros-Bernal F, Hunot S, Herrero MT, Parnadeau S, Corvol JC, Lu L, Alvarez-Fischer D, Carrillo-de Sauvage MA, Saurini F, Coussieu C, Kinugawa K, Prigent A, Hoglinger G, Hamon M, Tronche F, Hirsch EC, Vyas S: Microglial glucocorticoid receptors play a pivotal role in regulating dopaminergic neurodegeneration in parkinsonism. Proc Natl Acad Sci USA 2011, 108:6632-6637.

doi:10.1186/1742-2094-9-260

Cite this article as: Chantong et al:: Mineralocorticoid and glucocorticoid receptors differentially regulate NF-kappaB activity and pro-inflammatory cytokine production in murine BV-2 microglial cells. Journal of Neuroinflammation 2012 9:260.

\section{Submit your next manuscript to BioMed Central and take full advantage of:}

- Convenient online submission

- Thorough peer review

- No space constraints or color figure charges

- Immediate publication on acceptance

- Inclusion in PubMed, CAS, Scopus and Google Scholar

- Research which is freely available for redistribution 